AMERICAN JOURNAL OF FOOD AND NUTRITION

Print: ISSN 2157-0167, Online: ISSN 2157-1317, doi:10.5251/ajfn.2012.2.3.65.68

(C) 2012, ScienceHuß, http://www.scihub.org/AJFN

\title{
Amino acid profile of raw and extruded blends of African yam bean (Sphenostylis stenocarpa) and cassava flour
}

\author{
Gloria Chienyenwa Omeire
}

\author{
Department of Food Science and Technology,Federal University of Technology, Owerri \\ Corresponding Email: comeire@yahoo.com, Phone: 08065179082
}

\begin{abstract}
The main purpose of this work is to improve the low protein content of cassava based products. African yam bean (AYB) (Sphenostylis stenocarpa) seeds and cassava (Manihot exculenta, c) tubers were processed into flours. Extrusion runs were conducted using different ratios of feed blends in a single screw extruder $(0.54: 99.46 ; 20: 80 ; 50: 50 ; 80: 20 ; 99.46: 0.54)$ cassava flour/AYB flour. The raw and extruded products were subjected to amino acid analysis. All the amino acids in the raw samples appeared in the extruded products and were proportionally increased as the percentage of AYB increased. The results of the amino acid profile of cassava flour were generally lower except for arginine and glutamic acid, the highest level of loss for AYB was obtained in lysine (62.4\%), followed by glycine (47.43\%) and aspartic acid (44.96\%). Leucine had the lowest percentage loss of $14.14 \%$. The results indicated that extrusion cooking altered the amino acid profile of the extrudates and that blending increased the nutritional value of the products.
\end{abstract}

Keywords: Extrusion cooking, African yam bean, cassava flour, amino acid

\section{INTRODUCTION}

Extrusion cooking affects the nature of many food constituents, including starches and proteins by changing their physical, chemical and nutritional properties (Iwe et al., 2001).

Amino acid profile determines the quality of proteins in a given sample. In the developing world like Nigeria, extrusion cooking may be applied in the production of convenient foods from indigenous crops. Extrusion of blends of AYB and cassava flour (CF) will produce acceptable protein rich products that will meet the nutritional demand of the consumers. Cassava is the principal source of carbohydrate for communities that rely on it as a staple food. Cassava flour is gluten free and can be an appropriate baking or extruding ingredient for those with celiac disease. Protein content of cassava is low (Ogunjobi and Ogunwolu, 2010). The proteins of cassava tubers are rich in arginine but poor in methionine, lysine, tryptophan, phenylalanine and tyrosine, hence the complimentary with legumes.

Food legumes serve as an important economic source of supplementary protein for many populations lacking animal proteins. African yam bean (AYB) is one of the lesser known legumes produced in Nigeria. The protein content of AYB ranges from 19.6 - 29\% (Eka and Akaninwor, 2000). The lysine and methionine levels were reported to be equal or higher than those of soybean (Banigo, 2002). This study was aimed at extruding the blends of $A Y B$ and CF and analyzing the amino acid profile of the raw and extruded blends at different levels of substitution.

\section{MATERIALS AND METHODS}

Creamed coloured African yam bean seeds were purchased from a local market in Edda, Ebonyi State, Nigeria and cassava tubers (0505 variety) obtained from the experimental farm of the National Root Crop Research Institute (NRCRI) Umudike Abia State Nigeria were processed into flours. The flour samples were stored in air tight plastic containers at room temperature $\left(30 \pm 1^{\circ} \mathrm{C}\right)$ until used.

Five blends of cassava flour and AYB were formulated using the following ratios (0.54:99.46; $20: 80$; 50:50; 80:20; 99.46:0.54) cassava flour: AYB flour. The blends were extruded using a single screw extruder. The extruder temperatures were fixed at $90^{\circ} \mathrm{C}, 120^{\circ} \mathrm{C}$ and $110^{\circ} \mathrm{C}$ at feed, melt and die zones respectively. The amino acid profile for both the raw and some extruded products were determined using the method described by Spackman et al. (Spackman et al.,1958).

\section{RESULTS AND DISCUSSION}

The results obtained showed that the samples contained all the amino acids that are found in plant 
proteins (Table 1). The values obtained for AYB were generally higher than those obtained for cassava flour. The results showed that lysine content of AYB was 6.12 as against a report of 9.0 by Enwere (1998), but the result was in agreement with the report of Ekop, (2006) for cooked AYB seeds, also the values for some of the essential amino acids such as leucine, valine and threonine for AYB were in the same range as values stipulated by the $\mathrm{FAO} / \mathrm{WHO}$ for daily requirement. The variation in report of Enwere and this report in terms of lysine value of AYB may be attributed to the varietal differences, location or processing method used.

The results of the amino acid profile of cassava flours were generally lower except for arginine and glutamic acid. The results were in agreement with the report for the protein content of roots and tubers that are deficient in sulphur containing amino acids "methionine and cysteine" but are rich in branched chain amino acids such as arginine (Eka, 1998). The histidine value obtained for AYB was 3.10 which was higher than the values obtained from the cassava products (Table 2).
Table 1: Amino Acid Composition of AYB, Cassava Flour with $\mathrm{FAO} / \mathrm{WHO}$ stipulated daily requirement

\begin{tabular}{|l|l|l|l|}
\hline Amino Acid(g/100g) & AYB & $\begin{array}{l}\text { Cassava } \\
\text { Flour }\end{array}$ & $\begin{array}{l}\text { FAO/ } \\
\text { WHO }\end{array}$ \\
\hline Lysine & 6.12 & 3.00 & 5.52 \\
\hline Histidine & 3.10 & 0.13 & 2.41 \\
\hline Arginine & 6.47 & 9.02 & 2.01 \\
\hline Aspartic acid & 9.12 & 0.39 & ND \\
\hline Threonine & 3.25 & 1.49 & ND \\
\hline Serine & 3.05 & 0.30 & 4.01 \\
\hline Glutamic acid & 12.90 & 8.90 & ND \\
\hline Proline & 2.69 & 0.27 & ND \\
\hline Glycine & 3.90 & 0.29 & ND \\
\hline Alanine & 4.05 & 6.11 & ND \\
\hline Cystine & 1.56 & 0.65 & 3.52 \\
\hline Valine & 4.96 & 0.15 & 5.01 \\
\hline Methionine & 1.57 & 0.58 & 3.52 \\
\hline Isoleucine & 3.88 & 0.33 & 4.01 \\
\hline Leucine & 7.00 & 0.43 & 7.01 \\
\hline Tyrosine & 3.00 & 0.71 & 6.02 \\
\hline Phenylalanine & 5.05 & 0.25 & 6.02 \\
\hline
\end{tabular}

Key: $\mathrm{AYB}=$ African yam bean; $\mathrm{CF}=$ cassava flour; $\mathrm{C} 1=$ Exp Run for cassava $(125 \mathrm{rpm}, 16 \% \mathrm{MC}, 20 \% \mathrm{FC})$

C2 = Exp Run for cassava (125rpm, 16\%MC,80\%FC)

$\mathrm{C} 13=$ Exp run for cassava $(150 \mathrm{rpm}, 20 \% \mathrm{MC}, 0.54 \% \mathrm{FC})$

C14 = Exp. run cassava (150rpm,20\%MC,99.46\%FC)

$\mathrm{C} 15=$ Exp Run for cassava(150rpm,20\%MC,50\%FC)

Table 2: Amino acid profile of the raw and some extruded samples

\begin{tabular}{|l|l|l|l|l|l|l|l|}
\hline Amino acids (g/16gN) & AYB & CF & C1 & C2 & C13 & C14 & C15 \\
\hline Lysine & 6.12 & 3.00 & 2.20 & 2.60 & 2.30 & 2.26 & 2.01 \\
\hline Histidine & 3.10 & 0.13 & 2.07 & 2.00 & 2.23 & 1.88 & 1.16 \\
\hline Arginine & 6.47 & 9.02 & 4.08 & 4.68 & 5.02 & 4.25 & 3.23 \\
\hline Aspartic acid & 9.12 & 0.39 & 6.01 & 5.10 & 5.70 & 4.02 & 3.94 \\
\hline Threonine & 3.25 & 1.49 & 2.00 & 2.29 & 1.96 & 2.22 & 2.03 \\
\hline Serine & 3.05 & 0.30 & 1.78 & 1.90 & 2.03 & 1.02 & 1.08 \\
\hline Glutamic acid & 12.90 & 8.90 & 7.60 & 8.25 & 9.02 & 8.04 & 7.02 \\
\hline Proline & 2.69 & 0.27 & 1.06 & 1.50 & 1.21 & 0.96 & 0.89 \\
\hline Glycine & 3.90 & 0.29 & 2.02 & 2.25 & 2.05 & 1.56 & 1.09 \\
\hline Alanine & 4.05 & 6.11 & 2.32 & 3.06 & 2.50 & 1.85 & 2.05 \\
\hline Cystine & 1.56 & 0.65 & 0.73 & 0.80 & 0.95 & 0.73 & 0.75 \\
\hline Valine & 4.96 & 0.15 & 2.06 & 2.59 & 2.31 & 1.54 & 1.04 \\
\hline Methionine & 1.57 & 0.58 & 0.68 & 0.89 & 0.75 & 0.68 & 0.56 \\
\hline Isoleucine & 3.88 & 0.33 & 2.05 & 2.49 & 2.79 & 1.70 & 1.10 \\
\hline Leucine & 7.00 & 0.43 & 4.69 & 5.10 & 6.01 & 3.48 & 3.02 \\
\hline Tyrosine & 3.00 & 0.71 & 2.42 & 2.35 & 2.25 & 1.77 & 1.78 \\
\hline Phenylalanine & 5.05 & 0.25 & 3.47 & 3.88 & 4.00 & 3.13 & 3.06 \\
\hline
\end{tabular}

Key: $\mathrm{AYB}=$ African yam bean; $\mathrm{CF}=$ cassava flour;

$\mathrm{C} 1=$ Exp Run for cassava(125rpm,16\%MC,20\%FC)

$\mathrm{C} 2=$ Exp Run for cassava (125rpm,16\%MC,80\%FC)

$\mathrm{C} 13=$ Exp run for cassava (150rpm,20\%MC,0.54\%FC)

$\mathrm{C} 14=$ Exp. run cassava $(150 \mathrm{rpm}, 20 \% \mathrm{MC}, 99.46 \% \mathrm{FC})$

C15 = Exp Run for cassava(150rpm,20\%MC,50\%FC) 
AYB protein had been reported as a better source for infants in preparing weaning foods than soybean because of the higher content of histidine which according to Okaka et al., (1992) is an essential amino acid to infants. FAO/WHO/UNU estimated histidine requirement for infants of $3-4$ months was $28 \mathrm{mgkg}^{-1}$ day $^{-1}$ (Bowman and Russell, 2001). The AYB protein exceeded the amino acid requirement patterns for human adults for (Lysine 12mg, Histidine 08-12mg, Isoleucine 10mg, Leucine $14 \mathrm{mg}$, Phenylalanine and Tyrosine $14 \mathrm{mg}$ amino acid $) \mathrm{Kg}^{-1}$ day $^{-1}$ (FAO/WHO/UNU, 1985). The methionine and cystine values of AYB were low 1.57 and 1.56 respectively, which were the limiting amino acids in AYB. These observations agree with earlier investigation of other researchers (Oyenuga et al., 1974, Nwokolo, 1987, Apata and Ologhobo, 1994 , Ekop, 2006).

Blending AYB with cassava flour resulted to increase in the amino acid content of the blends. The result showed that blending of AYB and cassava products before extrusion marginally improved the nutritional value of the extrudates. Mendonca et al, (2005)

Table 3: Percentage changes in Amino Acid content of raw and extruded AYB, Ighu and Cassava flours.

\begin{tabular}{|c|c|c|c|c|c|c|}
\hline & AYB & & & CASSA & VA & \\
\hline Amino Acid(g/100g) & $\mathbf{R}$ & $\mathbf{E}$ & $\%$ & $\mathbf{R}$ & $\mathbf{E}$ & $\%$ \\
\hline Lysine & 6.12 & 2.30 & $62.40^{b}$ & 2.04 & 2.79 & $36.70^{\mathrm{a}}$ \\
\hline Histidine & 3.10 & 2.23 & $28.06^{b}$ & 0.29 & 1.50 & $80.60^{b}$ \\
\hline Arginine & 6.47 & 5.02 & $22.41^{\mathrm{D}}$ & 4.00 & 3.57 & $15.50^{\mathrm{b}}$ \\
\hline Aspartic acid & 9.12 & 5.70 & $44.96^{b}$ & 3.01 & 4.61 & $53.16^{\mathrm{a}}$ \\
\hline Threonine & 3.25 & 1.96 & $39.69^{b}$ & 1.29 & 1.58 & $22.48^{a}$ \\
\hline Serine & 3.05 & 2.05 & $33.44^{b}$ & 2.16 & 1.21 & $43.98^{a}$ \\
\hline Glutanine acid & 12.90 & 9.02 & $30.08^{b}$ & 5.01 & 6.48 & $29.34^{a}$ \\
\hline Proline & 2.69 & 1.21 & $55.02^{b}$ & 0.51 & 0.64 & $25.49^{a}$ \\
\hline Glycine & 3.90 & 2.05 & $47.43^{b}$ & 1.02 & 1.32 & $29.41^{a}$ \\
\hline Alanine & 4.05 & 2.50 & $38.20^{\mathrm{D}}$ & 0.19 & 2.55 & $92.55^{a}$ \\
\hline Cystine & 1.56 & 0.95 & $39.10^{b}$ & 0.45 & 0.66 & $46.67^{a}$ \\
\hline Valine & 4.96 & 2.31 & $53.42^{b}$ & 0.35 & 0.76 & $117.14^{2}$ \\
\hline Methionine & 1.57 & 0.75 & $52.22^{\mathrm{D}}$ & 0.46 & 0.68 & $47.83^{a}$ \\
\hline Isoleucine & 3.88 & 2.79 & $28.09^{b}$ & 0.79 & 1.77 & $124.05^{2}$ \\
\hline Leucine & 7.00 & 6.01 & $14.14^{b}$ & 2.38 & 3.65 & $53.36^{a}$ \\
\hline Tyrosine & 3.00 & 2.25 & $25.00^{b}$ & 1.59 & 1.61 & $1.26^{a}$ \\
\hline Phenyalanine & 5.05 & 4.00 & $20.79^{D}$ & 2.42 & 3.38 & $40.50^{a}$ \\
\hline
\end{tabular}

$\mathrm{R}=$ Raw; $\quad \mathrm{E}=$ Extruded; $\mathrm{a}=\%$ gain; $\mathrm{b}=\%$ loss
CONCLUSION: Blending improved the nutritional in plant proteins are contained in the extruded products. Extrusion cooking altered the amino acid profile of the extrudates. The operating variables had significant effects on cassava/AYB blends. The feed composition directly affected the protein content of the products. content of the extrudates. All the amino acids that are reported similar increase in amino acid profile for the mixture of amaranth and rice flours. Protein from plant sources still remains a major alternative source for the common man.

The percentage changes in the amino acid profile of the raw and extruded AYB samples (Table 3), revealed that the highest level of loss for AYB was obtained in lysine $(62.4 \%)$, followed by glycine $(47.43 \%)$ and aspartic acid (44.96\%). Leucine had the lowest percentage loss of $14.14 \%$. The results indicated that extrusion cooking reduced the amino acid values of AYB extrudates. The results are in agreement with the report of lwe et al. (2001), Nwabueze (2004) and Nwabueze (2007). Lysine processing (Colonna et al., 1989, Iwe et al., 2001, Nwabueze, 2004). Extrusion of mixtures containing proteins and a potential source of reducing sugars can result in losses in available lysine of up to $40 \%$ depending on water content and temperature (Stanley, 1989). serves as indicator of protein damage during

\section{REFERENCES}

Apata, D.F. and Ologhbo, A.D. 1994. Biochemical evaluation of some Nigerian legumes seeds. Food Chem. 49: $367-371$.

Banigo, E. B. 2002. Optimization of the level of incorporation of African yam bean (Sphenostylis stenocarpa) flour into comminuted meat type product 
as an extruder. Proceedings of the $26^{\text {th }}$ Annual Confeence of NIFST 2002. Pp $239-240$.

Colonna, P., Tayeb, J. and Mercier, C. 1989. Extrusion cooking of starch and starch products. In: C. Mercier, P. Linko, J.M. Harper editors. Extrusion cooking. Ass. of Cereal Chemists, St Paul MN p 247 - 319.

Eka, O. U. 1998. Roots and tubers. In. U. Osagie, and Offiong, U. Eka (eds) Nutritional quality of plant foods. Post harvest Research Unit. Benin City, Nigeria. P. 1-31.

Eka, E. B. and Akaninwor, J. O. 2000. Effect of Processing on the nutritional quality of African yam bean (spenostylis stenocarpa) and Bambara groundnut (Voandzeia subterrencea). Global J. Pure and Applied Sciences 6 (2): 181 - 188.

Ekop, A.S. 2006. Changes in amino acid composition of African yam beans (Sphenostylis stenocarpa) and African locust beans (Parkia filicoida) on cooking. Pakistan Journal of Nutrition 5(3) $254-256$.

Enwere, N. J. 1998. Foods of Plant Origin. Afro-Orbis Publications Ltd. Nsukka, Nigeria. Pp 24 - 76.

FAO/WHO/UNU. 1985. Food and Agriculture Organization of the United Nations, World Health Organization, United Nations University. Energy and protein requirements. Report of a Joint Expert Consultation. WHO Technical Report Series no.724. Geneva.

Iwe, M. O., Van Zuilichem, D. J., Ngoddy, P. O. and Wim Lanmers 2001. Amino acid and protein dispersibility Index (PDI) of mixtures of extruded soy and sweet potato flours. Lebensm - Wiss U. - technol., 34: 71 75.

Mendonca, X.M.F.D., Modesta,R.C.D., Ascheri,J.L.R., Maia,M.C.A., Ascheri,D.P.R. and Carvalho, C.W.P.
2005. Chemical characteristics and colour analysis of instant flours of amaranth and rice used in new extruded products Enpromer costa verde J. Brazil. Alimentaria. 367: $74-83$.

Nwabueze, T. U. 2004. Production and evaluation of cooked blends of African breadfruit (Treculia africana), corn (Zea mays) and soybean (Glycine max.) flours using a single screw extruder: A response surface analysis Ph.D. Thesis. Dept. of FST.MOUAU.Nigeria

Nwabueze, T.U. 2007. Nitrogen solubility index and amino acid profile of extruded African breadfruit ( $T$. africana) blends. Nigerian Food Journal. 23-35. http://www.bioline.org. br/request? Nfoj002.

Nwokolo, E. 1987. A nutritional assessment of African yam bean Sphenostylis stenocarpa (Hochst ex A Rich) Hams and Bambara groundnuts (Voandzeia subterranean L). J. Sci. Fd. Agric. 41: 123 - 129.

Ogunjobi, M.A.K. and Ogunwolu, S.O. 2010. Physicochemical and sensory Properties of cassava flour biscuits Suplemented with Cashew Apple Powder. Journal of Food Technology. Vol.8:1 pp 2429

Oyenuga, A.V., Fetuga,B.L. and Babatunde, G.M. 1974. Protein quality of some protein foodstuff. Studies on the African locust seed (Parkia filicoidea). Br.J.Nutr. 32:27-36.

Spackman, O. H.; Stein, E.H. and Moore, S. 1958. Automatic recording apparatus for use in the chromatography of amino. Analytical Chemistry. 30: 1190-1191.

Stanley, D. W. 1989. Protein reaction during extrusion processing. In: C. Mercier, P. Linko, J.M. Harper editors. Extrusion cooking. Ass. of Cereal Chemists, St Paul MN. P321-341. 